\title{
Presence of Arctotherium (Carnivora, Ursidae, Tremarctinae) in a pre-cultural level of Baño Nuevo-1 cave (Central Patagonia, Chile)
}

\section{Presencia de Arctotherium (Carnivora, Ursidae, Tremarctinae) en un nivel pre-cultural de cueva Baño Nuevo-1 (Patagonia Central, Chile)}

\section{P. López Mendoza ${ }^{1}$, F. Mena Larraín ${ }^{2}$, E. Bostelmann ${ }^{3}$}

1 Departamento de Antropología, Facultad de Ciencias Sociales, Universidad de Chile and ARQMAR-Centre for Maritime Archaeology Research of the Southeastern Pacific, Ignacio Carrera Pinto N ${ }^{\circ} 1045$, Ñuñoa, Santiago, Chile. Email: patriciolopezmend@gmail.com

2 Centro de Investigación en Ecosistemas de la Patagonia (CIEP; CONICYT-Regional R10C 1003), Simpson 471, Coyhaique, Chile. Email: francisco.mena@ciep.cl

3 Instituto de Ciencias de la Tierra, Facultad de Ciencias, Universidad Austral de Chile. Isla Teja s/n, Valdivia, Chile. E-mail: ebostel@yahoo.com

\section{ABSTRACT}

The description of an $\mathrm{I}_{3}$ assigned to Arctotherium sp. obtained from the Baño Nuevo-1 site (Central Patagonia, Chile) is presented. The finding was recovered from Layer 5 and it is associated to Macrauchenia sp., Lama guanicoe, Felidae, Camelidae, Equidae and Mylodontidae, within a sterile deposit of cultural material, dated between ca. 13.500 and 11.200 BP. Despite the fact that it is only a single specimen, such finding extends the known distribution for the genus in Chile.

Keywords: Ursidae; Arctotherium; Late Pleistocene; Central Patagonia.

\section{RESUMEN}

Se presenta la descripción de un $\mathrm{I}_{3}$ asignado a Arctotherium sp. proveniente del sitio Baño Nuevo-1 (Patagonia Central, Chile). El hallazgo fue realizado en la Capa 5 y está asociado a restos de Macrauchenia sp., Lama guanicoe, Felidae, Camelidae, Equidae y Mylodontidae dentro de un depósito estéril de material cultural, datado entre los ca. 13.500 y 11.200 años AP. Aunque se trata de un único espécimen, amplía el rango de distribución conocido para este género en Chile.

Palabras clave: Ursidae; Arctotherium; Pleistoceno final; Patagonia Central.

Citation / Cómo citar este artículo: P. López Mendoza, et al. (2015). Presence of Arctotherium (Carnivora, Ursidae, Tremarctinae) in a pre-cultural level of Baño Nuevo-1 cave (Central Patagonia, Chile). Estudios Geológicos 71(2): e041. http://dx.doi.org/10.3989/ egeol.42011.357.

Copyright: () 2015 CSIC. This is an open-access article distributed under the terms of the Creative Commons Attribution-Non Commercial (by-nc) Spain 3.0 License. 


\section{Introduction}

Recent evaluations of the Baño Nuevo-1 collections have led to the identification of an Arctotherium sp. (Carnivora, Ursidae, Tremarctinae) tooth fragment from the upper sections of Layer 5 (Late Pleistocene), associated to Macrauchenia sp., Equidae, Felidae, Lama guanicoe, Camelidae and Mylodontidae remains (mainly dermal bones). On the immediately overlaying Layer 4B, Diabolotherium cf. nordenskioldi, Lama guanicoe, Macrauchenia sp., Equidae, Camelidae, Felidae and Mylodontidae remains have also been recorded (López, 2009; Bostelmann, et al., 2011; López \& Mena, 2011).

This sample (one specimen) opens new issues for the osseous record of the final Pleistocene at the site, as another possible taphonomic agent has to be considered, while discussing the faunal remains founded on rockselters from this time period at the Chilean central Patagonia in general. Beyond description and taxonomic identification, it also opens new grounds for paleoecological studies, such as those already developed in southern Patagonia (Martín, 2008; 2013; Martín \& San Román, 2010).

The finding of an Arctotherium remain at Baño Nuevo-1 has been barely mentioned in previous studies (see López \& Mena, 2011). Given its importance, however, this brief note aims to provide valuable information on its stratigraphical setting and chronological context and a detailed description as well as a preliminary discussion on the origins of the fossil.

\section{The finding in context}

Baño Nuevo-1 is located ca. $80 \mathrm{~km}$, NE of Coyhaique $\left(45^{\circ} 17 \mathrm{~S}-71^{\circ} 32^{\prime} \mathrm{W}\right)$ (Fig. 1). The cave is located on an Aptian volcanic complex, locally known as "Cerro Grande del Campo Seis" (Large Hill on Section 6). With a depth of $20 \mathrm{~m}$ and an average width of $4 \mathrm{~m}$, the cave nowadays has a relatively restricted access due to the entry of coluvial debris fallen through a lateral shaft (Velásquez \& Mena, 2006). The stratigraphic record has been previously presented in several articles (see Mena et al., 2000, 2003; Núñez et al., 2005; Mena \& Stafford, 2006; Velásquez \& Mena, 2006; Mena, 2009; López \& Mena, 2011; Trejo \& Jackson 1998).

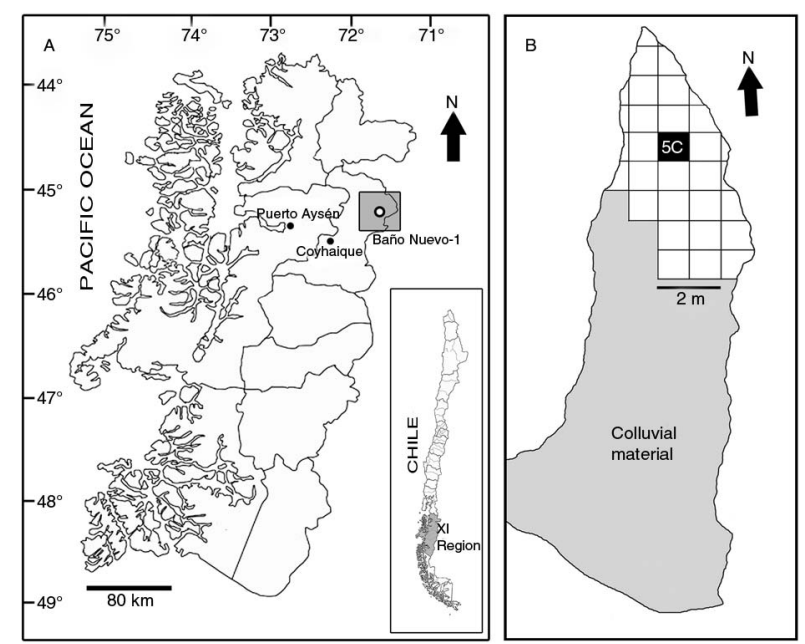

Figure 1.-A. Location of the Baño Nuevo-1 site; B. Plan drawing showing recovery location of the Arctotherium sp. sample.

The tooth specimen presented, was recovered from Layer 5, characterized by clay and organic sand, dated between $c a .13 .500$ and $11.200 \mathrm{cal}{ }^{14} \mathrm{C}$ B.P. (see Fig. 2). Just like Layer 4A, this layer presents abundant fossil remains and organic sediments that could be assigned to Mylodontidae dung (Mena \& Stafford, 2006; Núñez et al., 2005). This layer overlies Layer 6, composed by fine microlaminated sands deposited by a large Pleistocene proglacial lake devoid of any faunal remains (Mena \& Stafford, 2006; Núñez et al., 2005).

\section{Material and methods}

The material corresponds to a left $\mathrm{I}_{3}$. Currently, it is stored at the Facultad de Ciencias Sociales, Universidad de Chile, under the code Baño Nuevo-1/ Unidad 5C/Capa $5 / \mathrm{N}^{\circ} \mathrm{F} 171$. The specimen was compared with collections of Arctotherium vetustum at the Museo Argentino de Ciencias Naturales Bernardino Rivadavia, Lycalopex culpaeus, Otaria sp. and Puma concolor from the Laboratorio de Zooarqueología of the Universidad de Chile, and Panthera onca from a private collection. Since part of the cusp is broken, mesio-distal and lingual-labial measurements had to be taken only at the crown base. The occlusal surface was observed through Scanning Electron Microscopy (SEM) (Zeiss, model EVO MA10) at the Departamento de Antropología of the Universidad de Chile. 


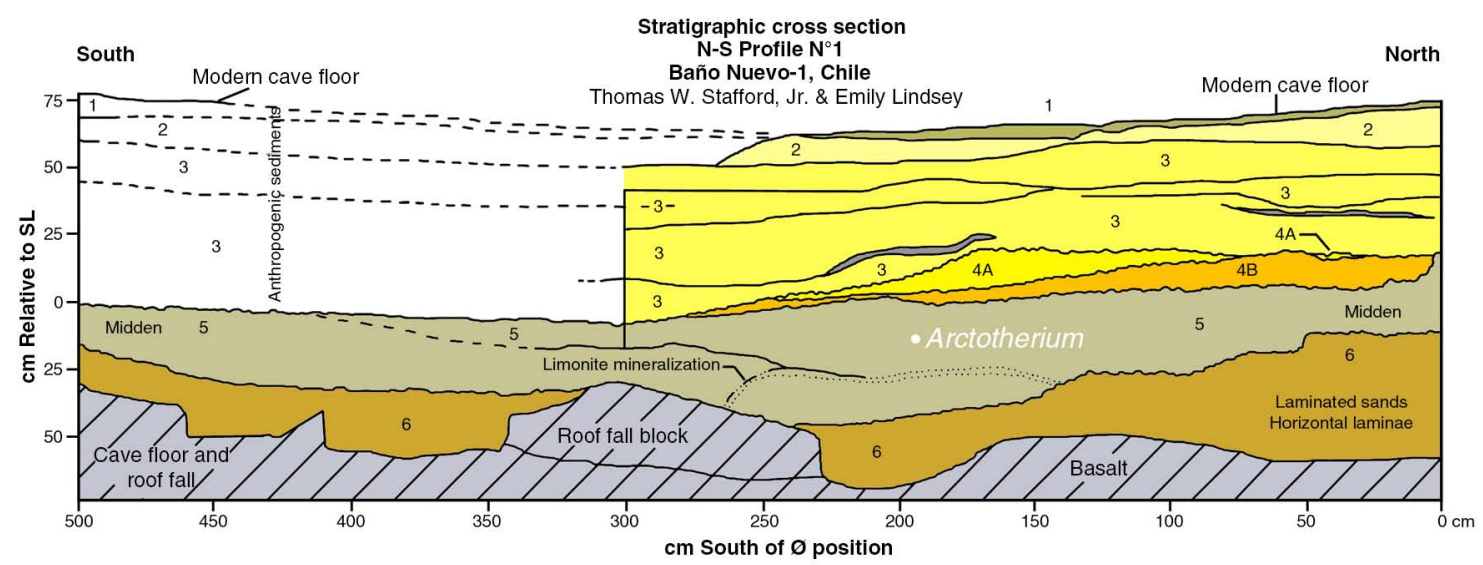

Figure 2.-Stratigraphic cross section of the Baño Nuevo-1 site.

Institutional abbreviations: MACN, Museo Argentino de Ciencias Naturales Bernardino Rivadavia.

\section{Systematic Paleontology}

Carnivora Bowdich, 1821

Ursidae Gray, 1825

Tremarctinae Merriam and Stock, 1925

Arctotherium Burmeister, 1879

Arctotherium sp.

Material: Baño Nuevo-1/Unidad 5C/Capa 5/N ${ }^{\circ}$ F171, an isolated $\mathrm{I}_{3}$ (Fig. 3A, B, C and D).

Geographical occurrence: Baño Nuevo-1 cave, Coyhaique, Central Patagonia, Chile. UTM: 0301821 E-4981638 N (Fig. 1A-B).

Stratigraphical occurrence: Layer 5, Late Pleistocene dated between $c a .13 .500$ and $11.200 \mathrm{cal}{ }^{14} \mathrm{C}$ B.P. (Fig. 2).

\section{Description and comparisons}

The small and fragmentary nature of the sample precludes a clear-cut, absolute identification, yet both its size and shape allows us to assign it to Ursidae and, moreover, to Arctotherium Burmeister, 1879. The finding was done on unit $5 \mathrm{C}$ and it corresponds to a left $\mathrm{I}_{3}$ from an adult. The incisor presents a fracture on its oclussal surface allowing us to see the pulp cavity of the tooth. This surface exhibits a subtriangular shape, while on the lingual facies we can see an enamel layer crossing the surface. The root also presents a subtriangular section being compressed on its messiodistal direction with two grooves reaching the dental crown and parallel edges. At the basis of the crown in the mesial level, the root rises to form an inverted $\mathrm{V}$, while on the distal surface we observe a well developed marginal lobe at the point where the crown meets the root, that is fractured on its occlusal surface (Fig. 3A, B, C and D).

The incisor from Baño Nuevo-1 was found to be much larger than those from canids, felids and otarids used as comparative references. It also presents a marked development of the marginal distal lobe and grooves on the root. None of these traits were observed on canids, felids or otarids. The specimen also presents a thick enamel layer on its labial face, being much thinner on the lingual one. Morphologically the Baño Nuevo-1 incisor is similar to Arctotherium vetustum (MACN 1201), although larger, with $8.5 \mathrm{~mm}$ mesio-distal measurement in the base and $12.6 \mathrm{~mm}$ labial-lingual measurement in the base.

\section{Biogeographic panorama}

Nowadays the Tremarctinae Subfamily can be found exclusively on the Americas (Soibelzon, 2004). Four genera are recognized: Plionarctos Frick, 1926 and Arctodus Leidy, 1854 in North America, Arctotherium Burmeister, 1879 in South America 


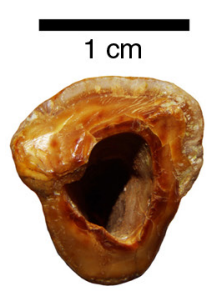

A
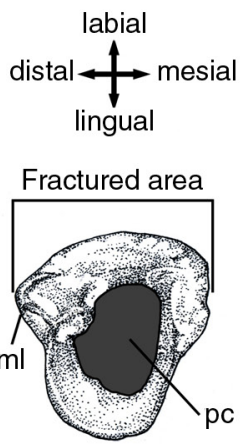

$\mathrm{E}$
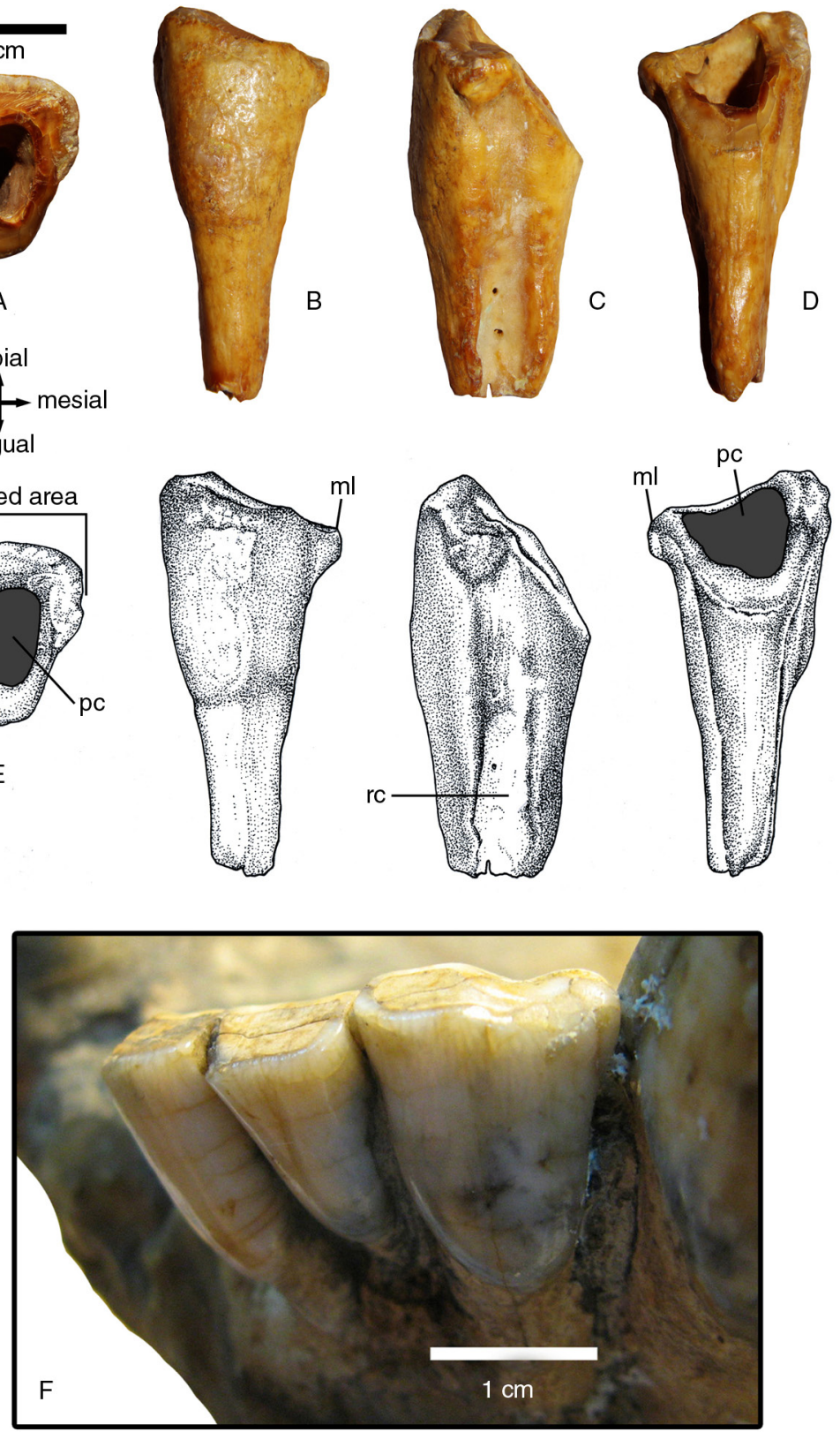

Figure 3.-Views from the de Arctotherium sp. $I_{3}$ from Baño Nuevo-1: A. Oclusal; B. Labial; C. Lateral; D. Lingual; E. Drawings of $\mathrm{I}_{3}$ of Arctotherium sp. of the Baño Nuevo-1 site indicating the principal features mentioned in the text; F. Arctotherium vetustum (MACN 1201) mandible with left $\mathrm{I}_{3}$ in situ. Abbreviations: ml. marginal lobe; pc. pulp cavity; rc. root canal.

and Tremarctos Gervais, 1855 with an extinct species from North America and a living one in South America (Soibelzon, 2004).

According to the latest reviews (Soibelzon, 2004; Soibelzon et al., 2005) the South American extinct bears have been assigned to the genera Arctotherium, being recorded in Venezuela, Brazil, Bolivia, Uruguay,
Argentina and Chile from the Ensenadan (Upper Pliocene to Middle Pleistocene) to the Lujanian (Upper Pleistocene-Early Holocene). Five species are recognized within this genera: Arctotherium vetustum Ameghino, 1885 from Bonaerian levels (Middle Pleistocene) at the Argentine provinces of Buenos Aires and Entre Ríos and one possible finding 
from Brazil; Arctotherium wingei Ameghino, 1902 from Brazilian and Venezuelan Lujanian levels and Pleistocene deposits in Bolivia; Arctotherium bonariense (Gervais 1848-1852) from Bonaerian and Lujanian levels of the Buenos Aires province (Argentina); Arctotherium angustidens Gervais \& Ameghino, 1880 from Ensenadan levels at the same province and at Tarija, Bolivia; and finally Arctotherium tarijense Ameghino, 1902 from Bonaerian and Lujanian levels at this Bolivian locality, Argentine provinces of Santa Fe and Buenos Aires, Uruguay and at the XII Region of Magallanes, Chile (Soibelzon, 2004).

In Chile, the record of Ursidae is restricted to central and southern Patagonia. It is composed by a molar from the Pilauco site $\left(40^{\circ} \mathrm{S}\right)$ assigned to Ursidae (Pino et al., 2013). Another finding corresponds to a femur from Cueva del Milodón $\left(51^{\circ} \mathrm{S}\right)$, originally assigned to Arctotherium sp. and later on reassigned to Pararctotherium pamparun by Oliver-Schneider (1935). At Cueva de Los Chingues (52 $\mathrm{S})$ an $\mathrm{I}^{2}$ was recorded. Originally assigned to Pararctotherium sp. by Prevosti et al. (2003), it was later identified as Arctotherium tarijense by Soibelzon (2004) and has recently been reassigned to Arctotherium sp. by Prevosti \& Martín (2013). Finally, there must be mentioned another femur fragment collected from the surface of Cueva del Puma $\left(52^{\circ} \mathrm{S}\right)$ and identified as Arctotherium tarijense with a date of $10.345 \pm 75$ B.P. (Martín et al., 2004, Martín, 2013). Thus, the evidence now reported from Baño Nuevo-1 fills the intermediate gap between the areas from where it was known before.

The Arctotherium sp. remain from Layer 5 at Baño Nuevo-1 cave is associated to Mylodontinae, Felidae (aff. Panthera onca mesembrina), Equidae, Lama guanicoe and Macrauchenia sp. remains with no traces of human presence (López \& Mena, 2011). Paleoenvironmental studies based on pollen records from neighboring areas (High Cisnes River, De Porras et al., 2012; High Simpson river, Markgraf et al., 2007; Middle Chacabuco river, Villa-Martínez et al., 2011) reveal an open steppe environment.

\section{Discussion and conclusions}

One of the questions triggered by the finding of Arctotherium at Baño Nuevo-1 is related to the taphonomy of the fossil assemblage at the cave.
Studies about the role of Arctotherium as a potential agent on the formation and transformation of bone assemblages are almost nonexistent, unlike the Old World Ursidae situation, whose taphonomic effects have been subject of intensive research (Gargett, 1996; D’Errico et al., 1998; Stiner et al., 1998; Wolverton, 2001; Quilès et al., 2006; Rabal-Garcés \& Cuenca-Bescós, 2009; Arilla et al., 2014). One of the few American studies, specifically geared to the case of Arctotherium angustidens, reveals a high proportion of broken teeth, as likely result of chewing on hard materials such as bones (Figueirido \& Soibelzon, 2010). On the other hand, studies by Haynes (1983) have revealed that bears (Ursus arctos and Ursus americanus in particular) leave traces like those made by rodents, that is short and parallel with punctures related to parallel grooves on the crest of long bones. Andrews and Fernández-Jalvo (1997) found punctures of up to $10.4 \mathrm{~mm}$ in diameter, attributed to the action of bears. These marks were recorded both on the shaft and articular surfaces, just like those findings done by D'Errico and collaborators (1998). The only puncture recorded on remains from Layer 5 at Baño Nuevo-1 was found on a Lama sp. patella and both its shape and size are consistent with those produced by canids.

However, with this finding, Arctotherium joins the Felidae (aff. Panthera onca mesembrina) and Dusicyon avus previously known from the site as potential agents in the formation of the bone assemblages from the layers of the Final Pleistocene at the site (Trejo \& Jackson, 1998). As said before, the wear patterns and dental pathologies observed in different samples indicate an omnivorous diet with non-negligible meat consumption, including bones (Prevosti \& Vizcaíno, 2006; Figueirido \& Soibelzon, 2010; Martín, 2013). In fact, most of the known Arctotherium angustidens remains have broken teeth's, most likely due to chewing on hard bones (Soibelzon et al., 2009; Figueirido \& Soibelzon, 2010).

In the occlusal surface of the $\mathrm{I}_{3}$ of Baño Nuevo-1, part of the cusp is fragmented and it presents a caries that could be interpreted as a result of eating carbohydraterich foods, such as fruit or honey (Ferigolo, 1992; Soibelzon \& Prevosti, 2007; Soibelzon et al., 2014). Though a microwear analysis is not applicable to South American giant short-faced bear, because in species with omnivore diet the interpretation of hard plant 


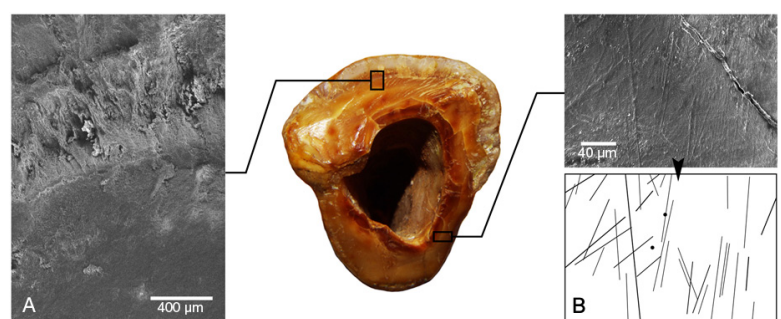

Figure 4.-Occlusal view of the $I_{3}$ of Baño Nuevo-1 showing: A. SEM photography of the area of fracture; B. SEM photography and schematic drawing indicating tracks of strias and pits product of the use as masticatory surface.

versus bone consumption is problematic (Soibelzon et al., 2014:1241), we performed a SEM observation to see microwear that could reveal chewing use after cusp breakage. We looked the labial and lingual faces of the occlusal surface, finding striations and pits that point to a chewing action on the lingual face, while no such traits were observed on the labial face (Fig. 4A-B). Such evidences points to a postdepositional fracture of a portion of the cusp, or an immediate loss of it together with the complete incisive from its alveolar cavity.

Given the lack of direct evidence of damage due to bear action, the origin of Arctotherium at Baño Nuevo-1 has to be questioned. Soibelzon and collaborators (2009) point to two possible scenarios for the presence of bears in caves: the use for hibernating, and the sporadic search of carrion inside the caves. Hibernation has been mentioned in other works (Martín, 2013:28), but it is not clear if it can be applied to Tremarctinae. Accordingly, the sporadic use of Baño Nuevo-1 cave for both food and shelter purposes, is the most plausible scenario, taking into account the number and sort of evidence recovered, along with no presence of taphonomic traces attributable to Arctotherium. In any case, this very low density of Arctotherium material is consistent with the record from other sites in Patagonia, such as Milodón, Los Chinges or El Puma caves, as it is the almost null evidence of taphonomic traces left by this taxon (Martín, 2008:364).

The record of Arctotherium at Baño Nuevo-1 raises several questions that must be dealt with in the future, such as the competition with other animals to occupy the cave or its role in the formation and transformation of the deposits.

\section{ACKNOWLEDGMENTS}

To Dr. Francisco Prevosti for his help identifying the sample, and his valuable comments to an earlier version of the manuscript. Thanks to the Museo Argentino de Ciencias Naturales Bernardino Rivadavia for granting the access to their collections. We also want to thank the anonymous reviewers and Elvira Latorre B. for her drawings.

\section{References}

Andrews, P. \& Fernández-Jalvo, Y. (1997). Surface modifications of the Sima de los Huesos fossil humans. Journal of Human Evolution, 33: 191-217. http:// dx.doi.org/10.1006/jhev.1997.0137

Ameghinio, C. (1885). Nuevos restos de mamíferos fósiles oligocenos, recogidos por el profesor Pedro Scalabrini y pertenecientes al Museo provincial de la ciudad de Paraná. Boletín de la Academia de Ciencias de Córdoba, 8: 3-207.

Ameghinio, C. (1902). Notas sobre algunos mamíferos fósiles nuevos o poco conocidos del valle de Tarija. Anales del Museo Nacional de Buenos Aires, 3: 225-261.

Arilla, M.; Rosell, J.; Blasco, R.; Domínguez-Rodrigo, M.; Pickering, T. (2014). The "bear" essentials: actualistic research on Ursus arctos arctos in the spanish pyrenees and its implications for Paleontology and Archaeology. PLoS ONE, 9 (7): e102457. http:// dx.doi.org/10.1371/journal.pone.0102457

Bostelmann, E.; López, P.; Salas-Gismondi, R. \& Mena, F. (2011). First record of Diabolotherium cf. nordeskioldi, Kraglievich 1926, (Mammalia, Tardigrada, Megalonychidae), from the Late Pleistocene of Chile. Ameghiniana, 48 (4): 146.

Bowdich, T.E. (1821). An analysis of the natural classificatons of Mammalia for the use of students and travellers. J. Smith, Paris. 115 pp.

Burmeister, H. (1879). Description physique de la République Argentine d'après des observations personnelles et étrangéres. Traduit de l'allemand avec le concourse de E. Daireaux. Tome troisiém. Animaux vertébrés. Premiére partie: Mammiféres vivants et éteints, 3 (1): 1-556 with Atlas.

D’Errico, F.; Villa, P.; Pinto Llona, A. \& Ruíz Idarraga, R. (1998). A Middle Palaeolithic origin of music? Using cave-bear bone accumulations to assess the Divje Babe I bone 'flute'. Antiquity, 72: 65-79. http://dx.doi.org/10.1017/S0003598X00086282

De Porras, M.E.; Maldonado, A.; Abarzúa, A.M.; Cárdenas, M.L.; Francois, J.P.; Martel-Cea, A.; Stern, Ch.; Méndez, C. \& Reyes, O. (2012). Postglacial vegetation, fire and climate dynamics at Central Chilean Patagonia (Lake Shaman, $44^{\circ} \mathrm{S}$ ). Quaternary Science Reviews, 50: 71-85. http://dx.doi.org/10.1016/j. quascirev.2012.06.015 
Ferigolo, J. (1992). Non-human vertebrate paleopathology of some Brazilian Pleistocene mammals. In: Paleopatologia and Paleoepidemiologia-Estudos Multidisciplinares (Araujo, A. \& Ferreira, L., Eds.), Panorama/ Escola Nacional de Saude Publica, Rio de Janeiro, 213-234.

Figueirido, B. \& Soibelzon, L. (2010). Inferring palaeoecology in extinct tremarctine bears (Carnivora, Ursidae) using geometric morphometrics. Lethaia, 43 (2): 209-222. http://dx.doi.org/10.1111/j.15023931.2009.00184.x

Frick, C. (1926). The Hemocyoninae and an American Tertiary Bear. American Museum of Ntural History Bulletin, 56: 1-110. http://hdl.handle.net/2246/1321

Gargett, R. (1996). Cave bears and modern human origins. University Press of America, Lanham, Maryland. 288 pp.

Gervais, P. (1855). Recherches sur les mammiféres fossiles de l'Amérique du Sud. In: Expédition dans les parties centrales de l'Amérique du Sud: De Rio de Janeiro á Lima, et de Lima au Para (Castelnau, F., dir.). Vol. 7, Zoologuie. Bertrand, Paris, 116 pp.

Gervais, P. (1848-1852). Zoologie et Paléontologie Francaises (animaux vertébrés) ou Nouvelles Recherches sur les Animaux Vivantes et Fossiles de la France. A. Bertrand, Paris, 271 pp.

Gervais, H. \& Ameghino, F. (1880). Los Mamíferos Fósiles de la América Meridional. F. Savy, Paris, 225 pp.

Gray, J.E. (1825). Outline of an attempt at the disposition of the Mammalia into tribes and families with a list of genera apparently appertaining to each tribe. Annals of Philosophy, 10: 337-344.

Haynes, G. (1983). A guide for differentiating Mammalian carnivore taxa responsible for gnaw damage to herbivore limb bones. Paleobiology, 9 (2): 164-172.

Leidy, J. (1854). Remarks on Sus americanus, or Harlanus americanus and other extinct mammals. Proceedings of the Academy of Natural Sciences of Philadelphia, 7: 89-90.

López, P. (2009). El mundo perdido de Patagonia Central: una aproximación tafonómica al estudio de los mamíferos extintos del sitio Baño Nuevo-1 (XI Región-Chile). In: Zooarqueología y Tafonomía en el Confín del Mundo (López, P.; Cartajena, I.; García, Ch. \& Mena, F., Eds.), Ediciones Universidad Internacional SEKChile, Santiago, 181-198.

López, P. \& Mena, F. (2011). Extinct ground sloth dermal bones and their role in the taphonomic research of caves: the case of Baño Nuevo-1 (Andean Central Patagonia, Chile). Revista Mexicana de Ciencias Geológicas, 28 (3): 519-532.

Markgraf, V.; Whitlock, C. \& Haverle, S. (2007). Vegetation and fire history during the last 19,000 cal yr B.P. in southern Patagonia: Mallín, Pollux, Coy-

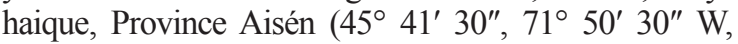
640 m elevation). Paleogeography, Paleoclimatology,
Palaeoecology, 254: 492-507. http://dx.doi.org/10.1016/ j.palaeo.2007.07.008

Martín, F. (2008). Bone Crunching felids at the end of the Pleistocene in Fuego-Patagonia, Chile. Journal of Taphonomy, 6 (3-4): 337-372.

Martín, F.M. \& San Román, M. (2010). Explorando la variabilidad del registro arqueológico y tafonómico en Pali-Aike (Chile) a través de la búsqueda de registros pleistocenos a cielo abierto. Magallania, 38 (1): 199-214. http://dx.doi.org/10.4067/S071822442010000100012

Martín, F. (2013). Tafonomía y paleocología de la transición Pleistoceno-Holoceno en Fuego Patagonia. Interacción entre humanos y carnívoros y su importancia como agentes en la formación del registro fósil. Ediciones de la Universidad de Magallanes, Punta Arenas. 406 pp.

Martín, F.; Prieto, A.; San Román, M.; Morello, F.; Prevosti, F.; Cárdenas, P. \& Borrero, L.A. (2004). Late-Pleistocene megafauna at Cueva del Puma, Pali-Aike Lava Field, Chile. Current Research in the Pleistocene, 21: 101-103.

Mena, F. (2009). Aves en Cueva Baño Nuevo. In: Zooarqueología y Tafonomía en el Confín del Mundo (López, P.; Cartajena, I.; García, Ch. \& Mena, F., Eds.), Ediciones Universidad Internacional SEKChile, Santiago, 59-71.

Mena, F., \& Stafford, T. (2006). Contexto estratigráfico y fechación directa de esqueletos humanos del Holoceno Temprano en Cueva Baño Nuevo (Patagonia Centra, Chile). In: Segundo Simposio Internacional el Hombre Temprano en América (Jiménez, J., Ed.), Instituto Nacional de Antropología e Historia, México, $139-154$.

Mena, F.; Lucero, V.; Reyes, O.; Trejo, V. \& Velásquez, H. (2000). Cazadores tempranos y tardíos en la Cueva Baño Nuevo-1, margen occidental de la estepa centropatagónica (XI Región de Aysén; Chile). Anales del Instituto de la Patagonia, 28: 173-195.

Mena, F.; Reyes, O.; Stafford, T. \& Southon, J. (2003). Early human remains from Baño Nuevo-1 cave, Central Patagonian Andes, Chile. Quaternary Internacional, 109-110: 113-121. http://dx.doi.org/10.1016/ S1040-6182(02)00207-0

Merriam, J. \& Stock, C. (1925). Relationships and structure of the short-faced bear, Arctotherium, from the Pleistocene of California. Carnegie Institution of Washington Publication, 347: 1-35.

Núñez, H., Stafford, T. \& Frassinetti, D. (2005). Primer registro de fósiles de Liolaemus en Chile (Reptilia, Sauria). Noticiario Mensual del Museo de Historia Natural, 356: 3-7.

Oliver-Schneider, C. (1935). Mamíferos fósiles de Chile: Adiciones y correcciones a la lista preliminar. Revista Chilena de Historia Natural, 39: 297-304.

Pino, M., Chávez-Hoffmeister, M., Navarro-Harris, X. \& Labarca, R. (2013). The late Pleistocene Pilauco site, 
Osorno, south-central Chile. Quaternary International, 299: 3-12. http://dx.doi.org/10.1016/j.quaint. 2012.05.001

Prevosti, F. \& Vizcaíno, S. (2006). Paleoecology of the large carnivore guild from the late Pleistocene of Argentina. Acta Palaeontologica Polonica, 51 (3): 407-422.

Prevosti, F. \& Martín, F. (2013). Paleoecology of the mammalian predator guild of Southern Patagonia during the latest Pleistocene: Ecomorphology, stable isotopes, and Taphonomy. Quaternary International, 305: 74-84. http://dx.doi.org/10.1016/j.quaint.2012.12.039

Prevosti, F.; Soibelzon, L.; Prieto, A.; San Román, M. \& Morello, F. (2003). The southernmost bear Pararctotherium (Carnivora: Ursidae: TreMartínae) in the latest Pleistocene of southern Patagonia, Chile. Journal of Vertebrate Paleontology, 23: 709-712. http://dx.doi. org/10.1671/0272-4634(2003)023 [0709:TSBPCU] 2.0.CO;2

Quilès, J.; Petrea, C.; Moldovan, O.; Zilhão, J.; Rodrigo, R.; Rougierf, H.; Constantin, S; Milota, S.; Gherase, M.; Sarcină, L.; \& Trinkaus, E. (2006). Cave bears (Ursus spelaeus) from the Peştera cu Oase (Banat, Romania). Comptes Rendus Palevol, 5: 927-934. http://dx.doi.org/10.1016/j.crpv.2006.09.005

Rabal-Garcés, R. \& Cuenca-Bescós, R. (2009). Tafonomía del yacimiento de osos de las cavernas de Coro Tracito (Tella, Huesca, España). Paleolusitana, 1: 397-402.

Soibelzon, L. (2004). Revisión sistemática de los Tremarctinae (Carnivora: Ursidae) fósiles de América del Sur. Revista Museo Argentino de Ciencias Naturales, 6: 107-133.

Soibelzon, L. \& Prevosti, F. (2007). Los carnívoros (Carnivora, Mammalia) terrestres del Cuaternario de América del Sur. In: Geomorfologia Litoral i Quaternari. Homenatge a Joan Cuerda Barceló (Pons, G. \& Vicens, D., Eds.), Monografies de la Societat d'Historia Natural de les Balears, Mallorca, 49-68.

Soibelzon, L.; Tonni, E. \& Bond, M. (2005). The fossil of South American short-faced bears (Ursidae,
Tremarctinae). Journal of South American Earth Sciences, 20: 105-113. http://dx.doi.org/10.1016/j. jsames.2005.07.005

Soibelzon, L.; Pomi, L.; Tonni, E.; Rodríguez, S. \& Dondas, A. (2009). First report of a South American short-faced bears' den (Arctotherium angustidens): palaeobiological and palaeoecological implications. Alcheringa, 33 (3): 211-222. http://dx.doi.org/10. 1080/03115510902844418

Soibelzon, L.; Grinspan, G.; Bocherens, H.; Acosta, W.; Jones, W.; Blanco, E.; Prevosti, F. (2014). South American giant short-faced bear (Arctotherium angustidens) diet: evidence from pathology, morphology, stable isotopes and biomechanics. Journal of Paleontology, 88 (6): 1240-1250. http://dx.doi. org/10.1666/13-143

Stiner, M.; Achyuthan, H.; Arsebük, G.; Clark Howell, F.; Josephson, S.; Juell, K.; Pigati, J. \& Quade, J. (1998). Reconstructing cave bear paleoecology from skeletons: a cross-disciplinary study of middle Pleistocene bears from Yarimburgaz Cave, Turkey. Paleobiology, 24 (1): 74-98.

Trejo, V. \& Jackson, D. (1998). Cánidos patagónicos: identificación taxonómica de mandíbulas y molares del sitio arqueológico cueva Baño Nevo-1 (Alto Nirehuao, XI Región). Anales del Instituto de la Patagonia 26: 181-194.

Velásquez, H. \& Mena, F. (2006). Distribuciones óseas de ungulados en la Cueva BañoNuevo-1/XIRegión, Chile): un primer acercamiento. Magallania, 34 (2): 91-106. http://dx.doi.org/10.4067/S0718-22442006000200009

Villa-Martínez, R., Moreno, P. \& Valenzuela, M.A. (2012). Deglacial and postglacial vegetation changes on the Eastern slopes of the central Patagonian Andes (47 S). Quaternary Science Reviews, 32: 86-99. http://dx.doi.org/10.1016/j.quascirev.2011.11.008

Wolverton, S. (2001). Caves, ursids, and artifacts: a natural-trap hypothesis. Journal of Ethnobiology, 21 (2): 55-72. 